\title{
ON THE EFECT OF ISONICOTIC ACID HYDRAZIDE UPON MURINE LEPROSY
}

\author{
SHINJI NISHIMURA and MICHIYUKI KONO \\ (Research Institute for Microbical Diseases, Osaka University) \\ TARO MASUDA \\ (1)epartment of Dermatology, Osaka liniversity Medical School)
}

The treatment and inhibitory effects of INAH upon rat leprosy are as following:

1) The administration of $1 \mathrm{mg}$. per day, six days in a week, was continued for five months. As the results, leprous ulcer was healed, leproma resorbed. The lepromas enveloped with thick connective tissue can not be easily resorbed, but they became harder and smaller in size.

2) Histological examination revealed storong proliferation of comective tissue in the lesions of local skin and regional lymph nodes. There was no appreciable lesion in the internal organs.

3) The longer the administration was continued, the more markedly disformed, granular murine leprosy bacilli were observed. But still they kept surviving force after each administration of $50 \mathrm{mg}, 90 \mathrm{mg}$ and $134 \mathrm{mg}$. There resuts were acertained from the seccessive inoculation with the treated leproma.

4) In the ustreated control animrls the cases of healing ulcers were observed, but in no case the leproma was completely resorbed, and bacilli and lesions were found in the viscera.

5) The animals which received treatment from the next day of inoculation produced no onset of the disease. But those which were inoculated with 20 thick bacilli susupension showed a slight difference from the untreated control animals.

To summarize the results, INAH is quite effective upon the murine leprosy. Though promin and tibione are favorable upon human leprosy and not upon murine leprosy, INAH produces better effect upon murine leprosy than human leprosy. From these facts, chemical agents useful to human leprosy are different from those favorable to murine leprosy. Therefore, animal experiments of leprosy treatment can not be applied to the research for a new drug, but to the explanftion of the bacteriostatic mechanism of the drugs against the murine leprosy bacilli.

\section{樌の化学療法に関する研究(第11報)$$
\text { 鼠瀬に対するイりニコチン酸ヒドラジッドの影響 }
$$

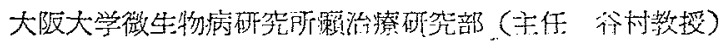

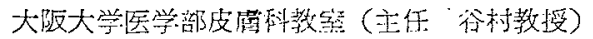

西村畺二浿野通之增田太䬦

(昭和28知 7月 10 日受科)

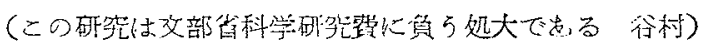

\section{はしがき}

ききにわれわれは，ヒドラジッドが発症鼠㿉に対して 治瘵的以可成優九大效果を現わしたととを中間報告と

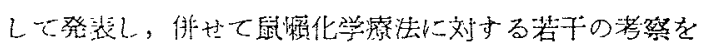
武车大。

本篇では治寮実弫の其の後の経過收び解剈所見と菌の

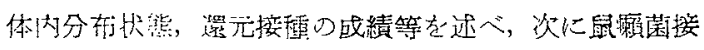




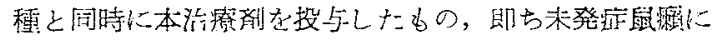
対する発症阻代作用について所兒を述べよ5と思ら。

\section{A 治療実験其の後の成綪}

\section{1) 実験材料及実験方法}

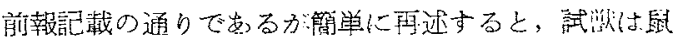

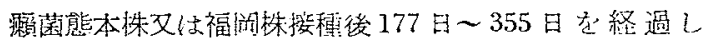

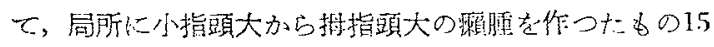
价を選び，体重 $140 \sim 265 \mathrm{~g}$, 平约 $200 \mathrm{~g}$ に対し I N $\wedge \mathrm{H}$ (ツベン)を乳糖又は澱粉で武形し特別の题で $3 \mathrm{mg}$ （重量 $1 \mathrm{my}$ ) つつ1日1回1週6日速続5ヶ月間経山 投与した。この歖は人体のブロキロ4 mgk相当する。

\section{2）実験成績（附㓙第 1 参照）}

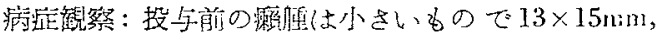
大きい例で $30 \times 25 \mathrm{~mm}$ ，多くは脱毛し，中には大きい溜

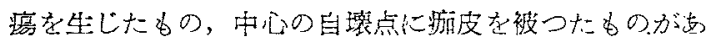

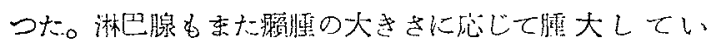
た。

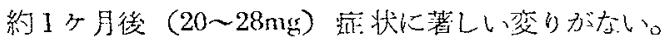
却つて涉琪を结じたものが多かつた。

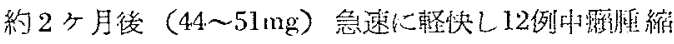

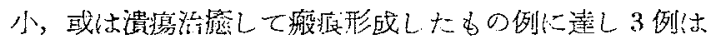
現状維持，1例は稍々增大した。

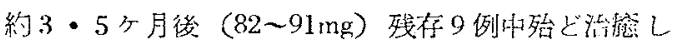

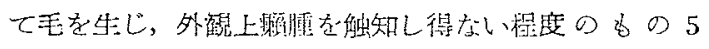

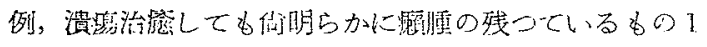
例，法滰前之殆ど资りないもの3例。

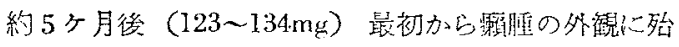
ど变りを見なかつた 3例（No2，No10，No15）を偉か

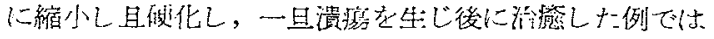

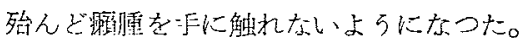

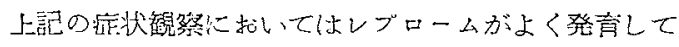

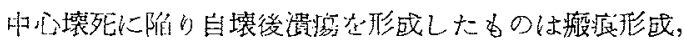

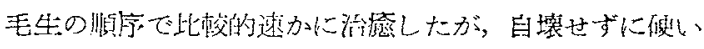

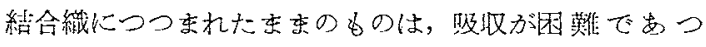

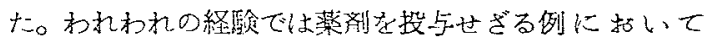

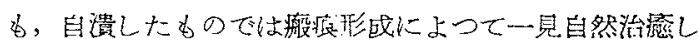
たかの姐き状熊を屡々見受けているが，この場合には深 部に残存走るレブロームの消失を見るまでにはとていい 加心。

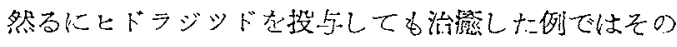

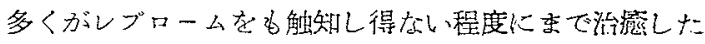
ことは判定上注目すべき点であると思う。

菌の体闪分布端びに形態1 ケ月目に数死した 3 例扣上 び2，3，4，5ヶ月と買を追つて解剖した新見では，

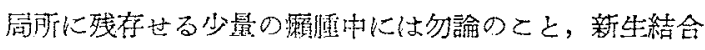
織中にも台多数の菌を認めることができた。ただしその 形態は起だ特異で殊に新生結合織中のるのは正形が極め て少く，大部分は菌体の染色不同で顆粒のみ強い䏽赤色

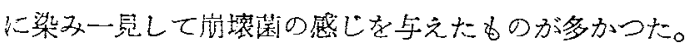

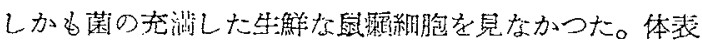

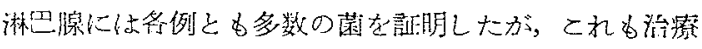
日数の進むに従つて尷減した。しかし5ヶ月では全く游

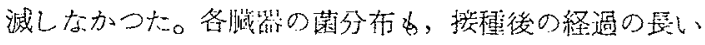
割含に䓈少数であつた。

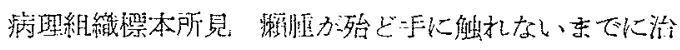

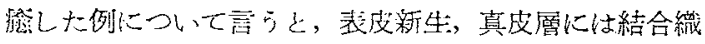

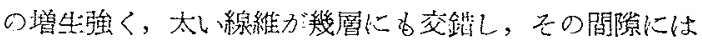

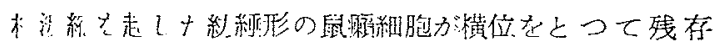


し，淋巴球もその間侵潤している。菌为顆粒状のもの が集国して見られた。

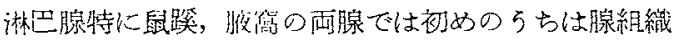

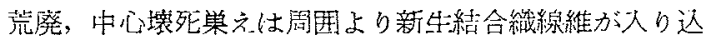
み修覆機転が現われていたが，ととにはな扎多数の顆粒

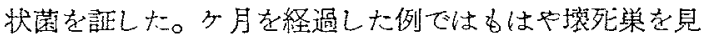
るとと少く，小結節が全体に亚つて点化ことに少数の得 を垫めた。又内腇も少数例に極好軽微な病変を認めた 程度で倬つ大。

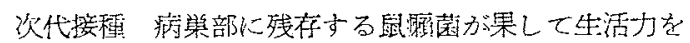
保持しているかどうかは，再発き拱抗囷の間題に関連し て電要であるから，これる白鼠へ次代援䅡するととによ つて㖑してみた。

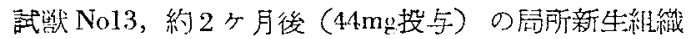

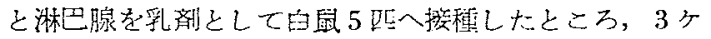
月後 5 呕に登原した。

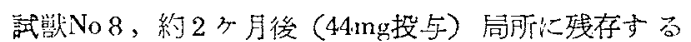

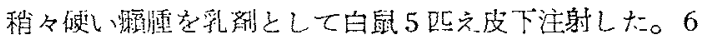
ヶ月後 IDCに発证した。

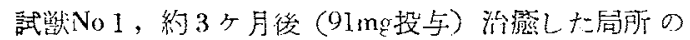
新生結合組織と淋巴腺老乳郕として白鼠入接種した。3 ヶ月後には発症を見なかつたが，5ケ見後には発症し to

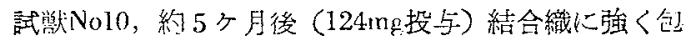

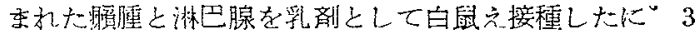
ヶ月後に発症した。

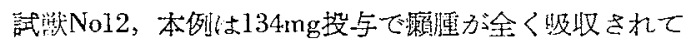
後6ヶ月を経過するも局所以再発を見なかつたものでめ

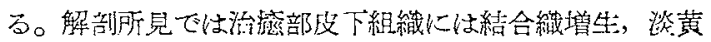

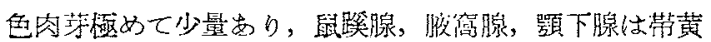
色稍々腫大戍化し，珠肌股简腺は被膜の肥厚を見る。鏡

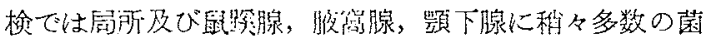

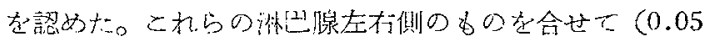

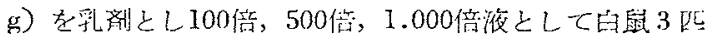

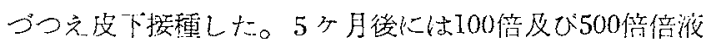
接䅨のbのは潮く螌知し得る程度に多症したが，1.000 倍液では発症を見なかつナ。

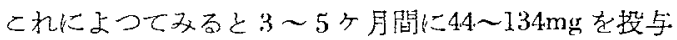

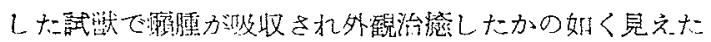

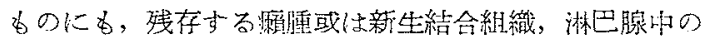

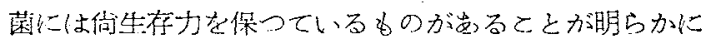

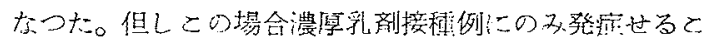
とは注目を献するととでもる。

\section{B 発症阻止実験}

\section{1) 実験方法}

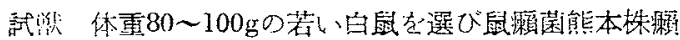
捚老20倍，200倍，1.000倍，10,000倍，100.000 倍比稀 歌乳戍とし，0.5ecを各群 5 匹つつつ皮下注射した。この

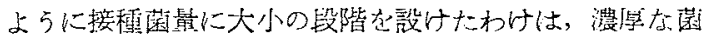
乳戍では往々にして菜郕の微細な效果を判定出来慕非、場 合があるからである。

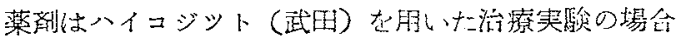
と同量を同じす法で投与した。
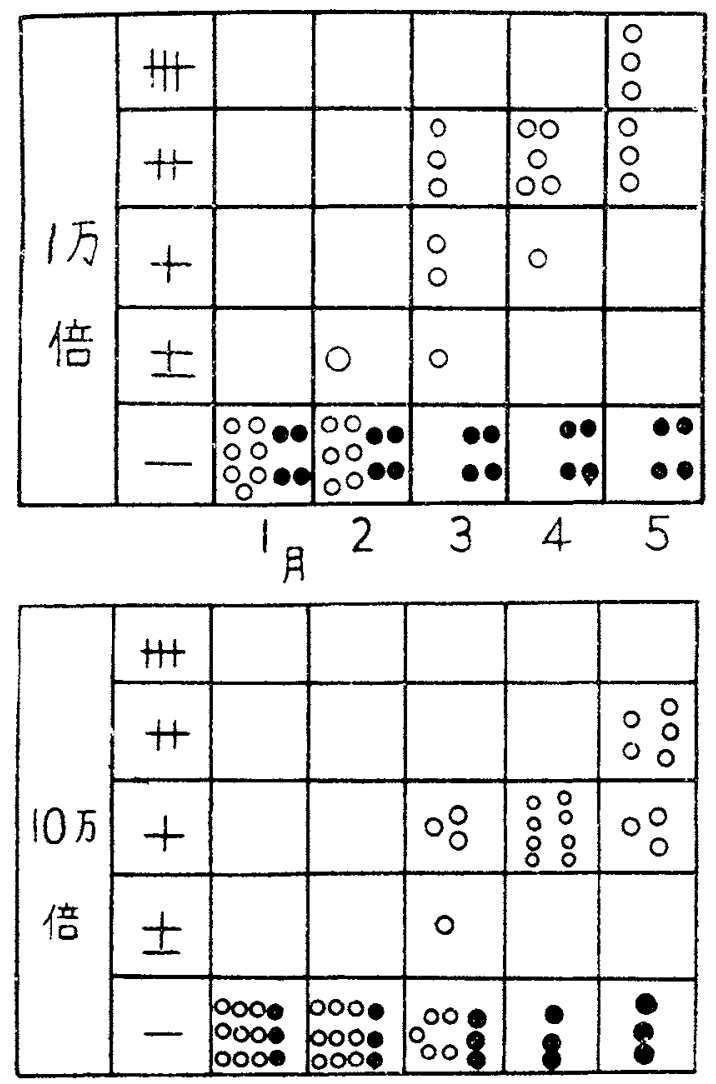

註

○対照

・ヒドラジット投与

土癩胿漸人手に触狄程度

十 米粒大 秘粒大

川川要大〜川指頭大

卅示指頭大 〜拇指頭大 
イソーコヂ酸しドラ゙゙ッドによる

発症阳此成績
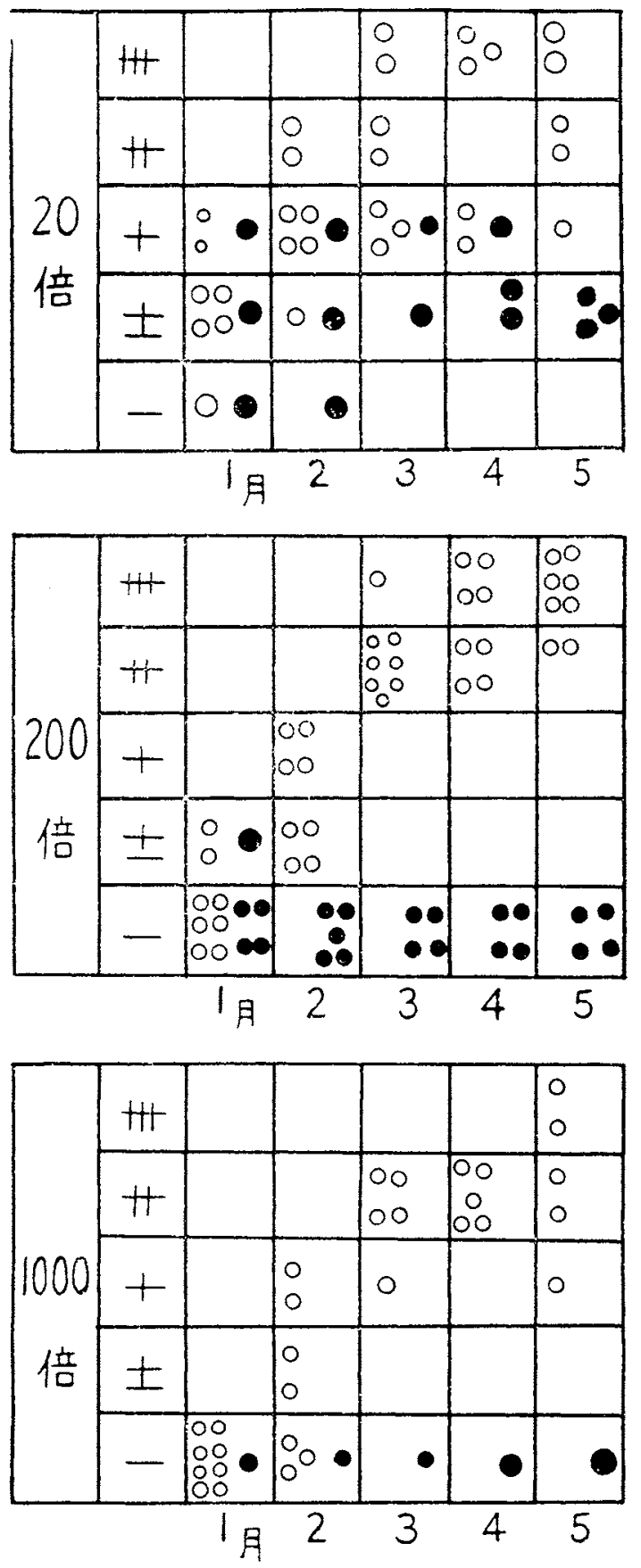

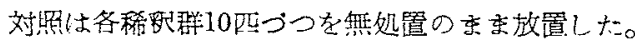

\section{2）実験成樍}

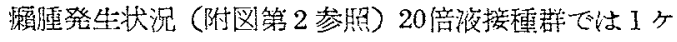
分目に投与群（○印），対照群（○）印の間に著しい盖

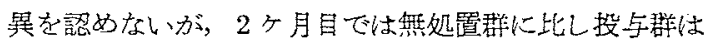

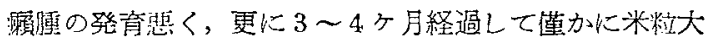
に発育したるのがもつたが 5 万後にはまたやつと触知 し得る程度化縮少した。然るに無処置諽では小亚大から 推指頭大に発育した。

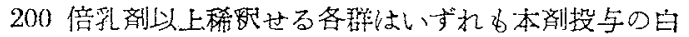
鼠儿は発症を見ず，完全心抑制されたが，枚照の各群て はいずれも霰腫を発生した。

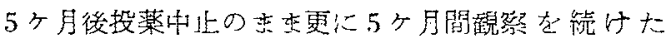

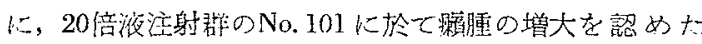
が，倬の耕似は全く变化なく完全に発生を芫なかつた。

解揢所兒之菌分布 (第 1 表参照)

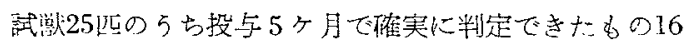

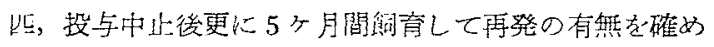

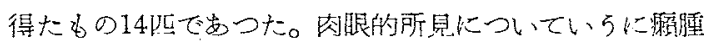

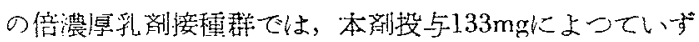
れる(士）程度で狮制されていることは間違いないが， 投与を中止して5ヶ月後には (H) 又は (十) 程度の発

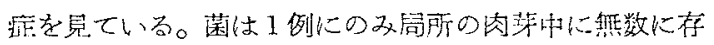

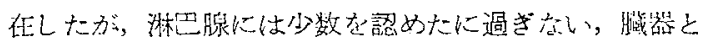

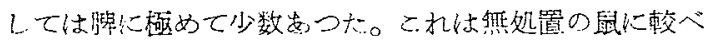
て著しく排制されてい西と見てよいようで出る。200倍

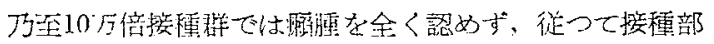
からは蔽を柃出できなかつたが湘巴腺ことに鼠觉腺及び 服腹腺には少数の菌が見られた。。だし櫭本中の菌は細

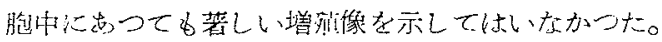

\section{むすび}

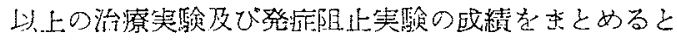
次のようである。

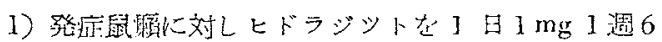

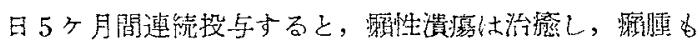
殆九ど吸收された。溃㿋を作らず厚い綪合織で包杂れた るのは吸収困難で老つた。てしてての場合菌の体内分布 は長期投与の例偍病资必軽く，菌の枱出必少かつた。

2）級織標本では治療した局所以結合織の增生が著い く淋四腺の壤死巣には明らかに修譏転が見られた。

3）ヒドラジット投与量では一旦洼湑した新生組織に

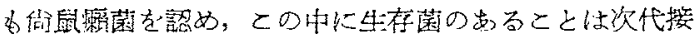




\section{イソーコチン酸ヒドラジッドによる治療成績}

\begin{tabular}{|c|c|c|c|c|c|c|c|c|c|c|c|c|c|c|c|c|c|c|c|c|}
\hline \multirow{2}{*}{$\begin{array}{l}\text { 試 } \\
\text { 盼 } \\
\text { NO } \\
\end{array}$} & \multirow[t]{2}{*}{ 性 } & \multirow{2}{*}{$\begin{array}{l}\text { 接 } \\
\text { 種 } \\
\text { 芭 } \\
\text { 株 }\end{array}$} & \multirow{2}{*}{$\begin{array}{l}\text { 接 } \\
\text { 種 } \\
\text { 凭 } \\
\text { 過百 }\end{array}$} & \multicolumn{2}{|c|}{ 治療前 } & \multirow{2}{*}{ 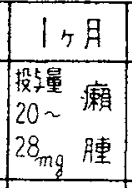 } & \multirow{2}{*}{ 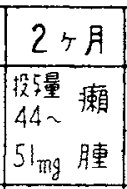 } & \multirow{2}{*}{ 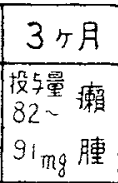 } & \multirow{2}{*}{ 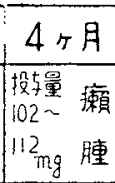 } & \multirow{2}{*}{ 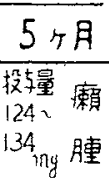 } & \multirow{2}{*}{$\begin{array}{l}\text { 䡆 } \\
\text { 歸 }\end{array}$} & \multicolumn{7}{|c|}{ 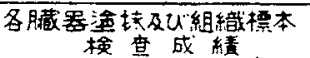 } & \multirow{2}{*}{$\begin{array}{l}\text { 判 } \\
\text { 定 }\end{array}$} & \multirow{2}{*}{$\left|\begin{array}{l}\text { 還 } \\
\text { 元 } \\
\text { 接 } \\
\text { 軖 }\end{array}\right|$} \\
\hline & & & & $\begin{array}{l}\text { 体 } \\
\text { 重 } \\
\end{array}$ & $\begin{array}{l}\text { 瀨 } \\
\text { 呺重m } \\
\end{array}$ & & & & & & & $\begin{array}{l}\text { 局 } \\
\text { 所 }\end{array}$ & 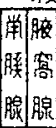 & 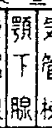 & & 楆 & & & & \\
\hline 1 & $q$ & $\begin{array}{l}\text { 熊 } \\
\text { 本 } \\
\text { 株 }\end{array}$ & 208 & 230 & $15 \times 15$ & & 0 & $\div$ & & & $\begin{array}{l}\text { 殺 } \\
321\end{array}$ & $\infty$ & ++ & & \pm- & & & - & $\begin{array}{l}\text { 治 } \\
\text { 癒 }\end{array}$ & \\
\hline 2 & $q$ & " & $"$ & 190 & $13 \times 13$ & & & & : & & $\begin{array}{l}\text { 死 } \\
382\end{array}$ & $\begin{array}{l}\infty \\
(++)\end{array}$ & $H+$ & & + & & & - & $\begin{array}{l}\text { 現 } \\
\text { 維 }\end{array}$ & + \\
\hline 3 & q & : & : & 195 & & & & & & & \begin{tabular}{|l|} 
殺 \\
371
\end{tabular} & $\begin{array}{l}\infty \\
(+)\end{array}$ & $++\cdots$ & & - & & & $(t)$ & $\begin{array}{l}\text { 治 } \\
\text { 癒 }\end{array}$ & + \\
\hline 4 & $\hat{\jmath}$ & " & " & 245 & & (10) & & & & 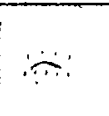 & $\begin{array}{l}\text { 死 } \\
456\end{array}$ & $\begin{array}{l}+ \\
(+)\end{array}$ & $+H$ & $+t$ & & + & & $( \pm \neq$ & $\begin{array}{l}\text { 治 } \\
\text { 瘭 }\end{array}$ & \\
\hline 5 & $\hat{\delta}$ & - & " & 240 & & (ه) & & & & & $\begin{array}{l}\text { 死 } \\
261\end{array}$ & + & ++ & - & & - & & - & $\begin{array}{l}\text { 軽 } \\
\text { 快 }\end{array}$ & \\
\hline 6 & 우 & $"$ & " & 155 & & & & & $\pi$ & & $\begin{array}{l}\text { 殺 } \\
371\end{array}$ & $\begin{array}{l}+1 \\
(+1)\end{array}$ & ++ & $+1+$ & & \pm & & $(4)$ & $\begin{array}{l}\text { 治 } \\
\text { 癒 }\end{array}$ & \\
\hline 7 & $\hat{\jmath}$ & " & " & 265 & & & & & & & $\begin{array}{l}\text { 死 } \\
239\end{array}$ & H⿻t & $H+H$ & -- & + & & & + & $?$ & \\
\hline 8 & $q$ & $"$ & 355 & 140 & 0 & & & & & & $\begin{array}{l}\text { 殺 } \\
417\end{array}$ & (N+) & $+H$ & $\pm=$ & \pm \pm & & \pm & + & $\begin{array}{l}\text { 治 } \\
\text { 瘛 }\end{array}$ & $f$ \\
\hline 9 & $\delta$ & " & " & 240 & & & & & & & $\begin{array}{l}\text { 死 } \\
375\end{array}$ & $\infty$ & $+n$ & ++ & & & & - & $?$ & \\
\hline 10 & $q$ & " & 177 & 140 & & & & & & & $\begin{array}{l}\text { 殺 } \\
330\end{array}$ & $\begin{array}{c}+ \\
(+N)\end{array}$ & ++ & $1+1-$ & & & & $m$ & $\begin{array}{l}\text { 現 } \\
\text { 維 }\end{array}$ & + \\
\hline 11 & $q$ & " & " & 140 & & & & $\ddot{P}$ & 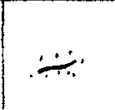 & & $\begin{array}{l}\text { 死 } \\
416\end{array}$ & $\begin{array}{c}+ \\
i+1\end{array}$ & ++ & $-9+$ & & & & - & $\begin{array}{l}\text { 治 } \\
\text { 癒 }\end{array}$ & \\
\hline 12 & $\hat{\delta}$ & : & $"$ & 145 & & & & & $\ldots$ & $\because$ & $\begin{array}{l}518 \\
518\end{array}$ & \# & $H$ & + \pm & \pm+ & \pm & & \pm & $\begin{array}{l}\text { 治 } \\
\text { 癒 }\end{array}$ & + \\
\hline 3 & $\hat{\jmath}$ & $\begin{array}{l}\text { 楅 } \\
\text { 葙 } \\
\text { 株 }\end{array}$ & 303 & 230 & & & & & & & $\begin{array}{l}x=2 \\
314\end{array}$ & $\begin{array}{l}+ \\
1+1\end{array}$ & ++ & + & \pm & & ++ & + & $\begin{array}{l}\text { 治 } \\
\text { 㾤 }\end{array}$ & + \\
\hline 14 & q & “ & ' & 170 & & & & & & & 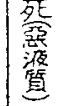 & & & & & & & & $?$ & \\
\hline 15 & $q$ & . & & 180 & & & & & & & $\begin{array}{l}\text { 死 } \\
456\end{array}$ & \begin{tabular}{|l|}
$+m$ \\
$(+1+1)$
\end{tabular} & ++ & & & & & - & $\begin{array}{l}\text { 現 } \\
\text { 維 }\end{array}$ & \\
\hline
\end{tabular}

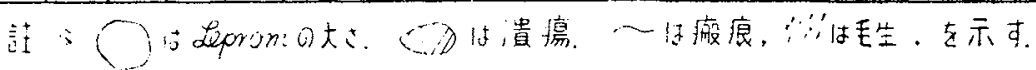

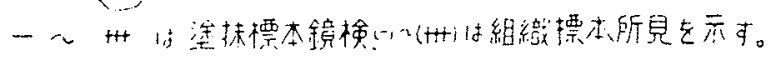




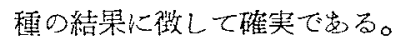

4) 蔽の形熊は長期坄与の例性ど変形して顆粒状を呈 するもの多く，淋巴腺組織们にも菌の充濊したラング八 ンス型国態細胞をみるととが沙心。

5）菌接種の翌日から本剤を投与したものでは確実儿

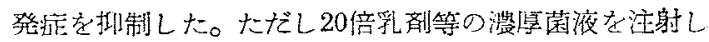

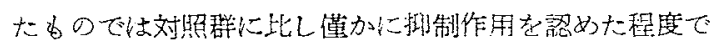
岕る。

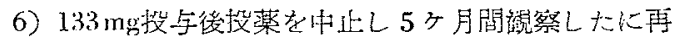

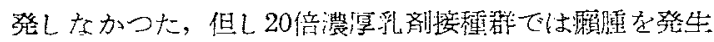

したものがつた。

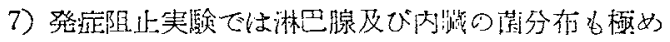

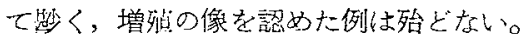

以上によつてヒドラジットは，われわれが鼠瘄に対し

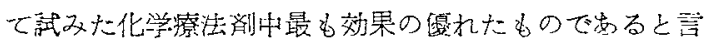
つてよいように思う。

\section{交献}

西村真二，河野通之：ヒドラジッドによる鼠制の治療

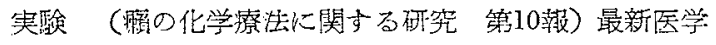
第 7 卷11昘97真

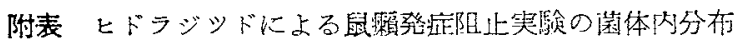

\begin{tabular}{|c|c|c|c|c|c|c|c|c|c|c|c|c|c|c|c|c|}
\hline \multirow{2}{*}{ 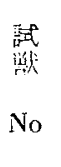 } & \multirow[b]{2}{*}{ 性 } & \multirow{2}{*}{$\begin{array}{l}\text { 菌 } \\
\vdots \\
\vdots \\
\vdots \\
\vdots\end{array}$} & \multicolumn{2}{|c|}{ 癩＼cjkstart腫 } & $5 \preccurlyeq$ 月 後 & \multicolumn{3}{|c|}{ 㭡 } & \multicolumn{3}{|c|}{ 体 } & \multicolumn{2}{|l|}{ 闪 } & \multicolumn{2}{|c|}{ 布 } & \multirow[b]{2}{*}{ 䈆 } \\
\hline & & & $\begin{array}{l}\text { 投与 } \\
5 \% \text { 月 } \\
133 \mathrm{mg}\end{array}$ & $\begin{array}{l}5 \text { 据後 } \\
5 \text { 月 }\end{array}$ & 解 㨽 所 晃 & $\begin{array}{l}\text { 间 } \\
\text { 所 }\end{array}$ & 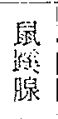 & $\begin{array}{l}\text { 望 } \\
\text { 留 } \\
\text { 腺 }\end{array}$ & 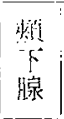 & 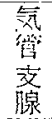 & 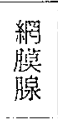 & \begin{tabular}{|l} 
腰 \\
部 \\
腺
\end{tabular} & 脑 & 肘 & 脾 & \\
\hline 1.01 & $s$ & $\times 20$ & \pm & H & 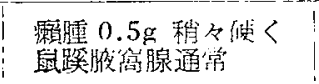 & $\infty$ & + & + & - & - & - & + & - & - & + & - \\
\hline 102 & $\hat{o}$ & & \pm & & $\ldots \ldots$ & $\ldots$ & $\ldots$ & - & $-\cdots$ & $\ldots$ & $\cdots$ & $\cdots$ & - & & - & - \\
\hline 104 & $\delta$ & $0.5 \mathrm{cc}$ & \pm & + & 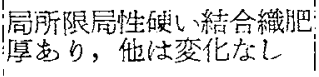 & + & - & $\perp$ & - & - & - & $\perp$ & - & - & - & - \\
\hline 111 & $q$ & & - & - & 尚所及び淋罠腺变化な & - & + & + & - & - & - & - & - & - & - & - \\
\hline 112 & $q$ & $\times 200$ & - & - & 上. & - & + & + & - & - & - & - & - & - & - & - \\
\hline 1.13 & q & $0.5 * \mathrm{c}$ & - & - & 上 & - & + & + & - & - & - & - & - & - & -- & - \\
\hline 114 & $q$ & & - & & & ..... & $\ldots$ & - & - & 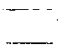 & -- & - & $\ldots$ & - & $\cdots$ & $\ldots$ \\
\hline 115 & $\hat{s}$ & & - & - & 局所及び淋巴腺姿化な & - & + & + & - & - & - & - & - & - & - & - \\
\hline 121 & $\delta$ & $\mid \begin{array}{l}\times 1000 \\
0.5 \mathrm{cc}\end{array}$ & - & - & 局所及び淋巴腺変化な & - & + & + & - & - & - & - & - & - & - & - \\
\hline ]31 & 우 & & - & - & $\begin{array}{l}\text { 呞所及び淋巴腺变化な } \\
\text { L }\end{array}$ & - & + & + & - & - & - & - & - & - & - & - \\
\hline 132 & 우 & $\times 1$ 万 & - & - & 间 & - & + & + & - & - & - & - & - & - & - & - \\
\hline 133 & $q$ & $0.5 \mathrm{ce}$ & - & - & {$\left[\begin{array}{ll} \\
{[i]}\end{array}\right.$} & - & $\perp$ & - & - & - & - & - & - & - & - & - \\
\hline 134 & 9 & & - & - & 上 & - & - & - & - & - & - & - & - & -. & - & - \\
\hline 142 & q & & - & - & 局䓄及び淋巴腺变化た & - & $\perp$ & $\perp$ & - & - & - & - & - & - & - & - \\
\hline 143 & f & $\int_{0}^{x}$ & - & - & 上 & - & $\perp$ & - & - & - & - & - & - & - & - & - \\
\hline 145 & क & & - & - & 同 & - & $\div$ & - & - & - & - & - & - & - & - & - \\
\hline
\end{tabular}

